TEACHING ARTISTIC RESEARCH 


\section{editıon: 'AngewAndtə}

Book Series of the University of Applied Arts Vienna

Edited by Gerald Bast, President 
CONVERSATIONS ACROSS CULTURES

\section{TEACHING ARTISTIC RESEARCH}

Edited by

Ruth Mateus-Berr

Richard Jochum 
